The Canadian Mineralogist

Vol. 44, pp. 1171-1179 (2006)

\title{
SHORT-RANGE ORDER IN AMPHIBOLES FROM THE BEAR LAKE DIGGINGS, ONTARIO
}

\author{
FRANK C. HAWTHORNE ${ }^{\S}$ AND ROBERTA OBERTI
}

CNR - Isituto di Geoscienze e Georisorse, Unità di Pavia, via Ferrata 1, Pavia, Italy

\author{
ROBERT F. MARTIN
}

Department of Earth and Planetary Sciences, McGill University, 3450 University Street, Montreal, Quebec H3A 2A7, Canada

\section{ABSTRACT}

The crystal structures of four amphiboles from the Bear Lake diggings, in the Bancroft area of Ontario, fluorotremolite, fluororichterite and two samples of potassian fluor-magnesiokatophorite, have been refined to $R$ indices in the range 1.5-2.2\%

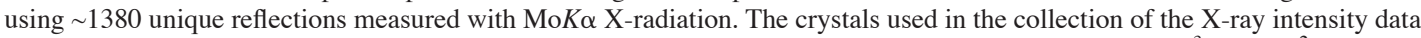
were subsequently analyzed by electron and ion microprobes, and formulae were calculated using the $\mathrm{Fe}^{3+}$ and $\mathrm{Fe}^{2+}$ contents established by crystal-structure refinement. Site populations were assigned from the results of site-scattering refinement and stereochemical analysis, taking into account the unit formula determined for each crystal. Difference-Fourier maps through the $A(2 / m)$ site show that the $A(m)$ site is occupied and the $A(2)$ site is vacant in all crystals. Occupancy of the $A(m)$ site, and not the $A(2)$ site, by $\mathrm{Na}$ imposes strong constraints on the possible patterns of short-range order in these amphiboles. The site populations of the $A(m), M(4)$ and $\mathrm{O}(3)$ sites are in accord with the local arrangement ${ }^{A(m)}(\mathrm{Na}+\mathrm{K}){ }^{\mathrm{O}}{ }^{(3)} \mathrm{F}-{ }^{M(4)} \mathrm{Na}$, with lesser amounts of ${ }^{A(m)}(\mathrm{Na}+\mathrm{K})-^{\mathrm{O}(3)} \mathrm{OH}-{ }^{M(4)} \mathrm{Na}$ and major to minor amounts of ${ }^{A} \square-{ }^{\mathrm{O}(3)} \mathrm{OH}-{ }^{M(4)} \mathrm{Ca}$. The coupling of elements to specific shortrange-ordered arrangements in these crystals suggests that the overall chemical variability of amphiboles is strongly constrained by local bond-valence restraints in addition to overall electroneutrality.

Keywords: amphibole, crystal-structure refinement, site populations, electron-microprobe analysis, SIMS analysis, short-range order, Bear Lake diggings, Ontario.

\section{SOMMAIRE}

Nous avons affiné la structure cristalline de quatre échantillons d'amphibole provenant de l'indice de Bear Lake, près de Bancroft, en Ontario, fluorotrémolite, fluororichterite et deux cristaux de fluor-magnésiokatophorite potassique, jusqu'aux résidus $R$ dans l'intervalle 1.5-2.2\% en utilisant environ 1380 réflexions uniques, mesurées avec rayonnement MoKa. Les cristaux utilisés ont par la suite été analysés avec une microsonde électronique et une microsonde ionique, et les formules ont été calculées avec les proportions de $\mathrm{Fe}^{3+}$ et de $\mathrm{Fe}^{2+}$ établies par l'affinement structural. L'occupation des sites a été assignée à partir des affinements de la dispersion associée à chaque site et par analyse stéréochimique, en tenant compte des formules élémentaires de chaque cristal. La distribution des électrons obtenue par différence-Fourier au site $A(2 / m)$ montre que le site $A(m)$ est rempli, mais le site $A(2)$ est vide dans les quatre cas. Le taux d'occupation par $\mathrm{Na}$ au site $A(m)$, et non au site $A(2)$, impose de fortes contraintes sur les schémas possibles de mise en ordre à courte échelle dans ces amphiboles. La population des sites $A(m), M(4)$ et $\mathrm{O}(3)$ concorde avec l'arrangement local ${ }^{A(m)}(\mathrm{Na}+\mathrm{K}){ }_{-}{ }^{\mathrm{O}(3)} \mathrm{F}-{ }^{M(4)} \mathrm{Na}$, avec une proportion moindre de ${ }^{A(m)}(\mathrm{Na}+\mathrm{K})-^{\mathrm{O}(3)} \mathrm{OH}-{ }^{M(4)} \mathrm{Na}$, et des proportions majeures ou mineures de ${ }^{A} \square-{ }^{\mathrm{O}(3)} \mathrm{OH}-{ }^{M(4)} \mathrm{Ca}$. Le couplage des éléments dans ces agencements locaux bien spécifiques fait penser que la variabilité en composition des amphiboles est fortement régie par les contraintes imposées par les valences de liaisons locales, en plus des exigeances d'électroneutralité.

(Traduit par la Rédaction)

Mots-clés: amphibole, affinement de la structure cristalline, populations des sites, analyse par microsonde électronique, analyse par microsonde ionique, mise en ordre à courte échelle, indice de Bear Lake, Ontario.

$\S$ Now frozen in the Department of Geological Sciences, University of Manitoba, Winnipeg, Manitoba R3T 2N2, Canada. E-mail address: frank_hawthorne@umanitoba.ca 


\section{INTRODUCTION}

Hawthorne et al. (1996b) showed that short-range order (SRO) occurs in amphibole of tremolitic composition with significant contents of ${ }^{A(m)}(\mathrm{Na}+\mathrm{K}),{ }^{M(4)} \mathrm{Na}$ and ${ }^{\mathrm{O}(3)} \mathrm{F}$. Subsequent work on synthetic amphiboles involving both homovalent (Della Ventura et al. 1998, Robert et al. 2000) and heterovalent (Della Ventura et al. 1999, 2003, Hawthorne et al. 2000) substitutions has shown that SRO is a common feature of amphiboles. Hawthorne (1997) extended bond-valence theory (Brown 1981, 2002) to local arrangements in crystals and showed that local bond-valence requirements in amphiboles are optimized if specific arrangements of atoms occur at the local level (i.e., they will occur with much greater frequency than a random occurrence of local arrangements would suggest), while other arrangements are not stable (they will not occur or will occur at a much lower frequency than a random occurrence of local arrangements would suggest). Here, we examine a series of amphiboles from the Bear Lake mineral-collecting locality, Ontario, with regard to the occurrence of SRO.

\section{Geological Setting And Sample Description}

The Bear Lake diggings, well-known to the mineralcollecting community, is located $8.4 \mathrm{~km}$ west of Tory Hill, Monmouth Township, in the Bancroft District of southeastern Ontario. Narrow "vein-dikes" of "carbonatite" are emplaced in rocks of the Glamorgan complex, consisting mostly of quartzofeldspathic gneiss, amphibolite and marble (Armstrong \& Gittins 1968). The complex equilibrated in the amphibolite grade during the first pulse of the Grenvillian Orogeny, dated between 1190 and $1170 \mathrm{Ma}$ (Easton 2000). The supracrustal rocks were buried to $25 \mathrm{~km}$ or so, where they attained a temperature close to $650^{\circ} \mathrm{C}$ (Anovitz \& Essene 1990, Streepey et al. 1997). Then, upon decompression and thermal contraction, undeformed dikes of calcite of controversial origin were emplaced in the waning stages of the Grenville event.

The calcite dikes likely were emplaced between 1070 and $1040 \mathrm{Ma}$ ago, at a stage of regional distension after important thrusting. The dikes are steep and subparallel, and run approximately east-west. They typically are 1 to 2 meters across, locally swell to over $3 \mathrm{~m}$, and pinch out at irregular intervals in an en échelon fashion. Such tension gashes were possibly filled with a crust-derived silicate-bearing carbonatitic melt (via marble syntexis; $c f$. Lentz 1998). This low-viscosity magma crystallized the coarse euhedral crystals of amphibole (BL8, BL10 and BL11, Table 1), biotite, sanidine solid-solution (now coarsely exsolved to orthoclase perthite), titanite, augite, zircon, and fluorapatite so highly prized by collectors. These crystals, up to $5 \mathrm{~cm}$ across and compositionally homogeneous, generally protrude from the walls into the body of coarsely crystalline calcite, but they also are found away from the walls, completely enclosed by calcite. The temperature of crystallization of the assemblage was above the crest of the alkali feldspar solvus (above $\sim 625^{\circ} \mathrm{C}$ ), resulting in the "single crystals" of perthite. Small masses of calc-silicates and carbonate also are found locally in the country rock along the contact with the dikes, possibly part of a skarn assemblage. The fluorotremolite BL TREM (Table 1) is from such an assemblage of calc-silicates. From the spatial and paragenetic relations of the four amphiboles, it is apparent that they all crystallized or equilibrated at the same temperature. The four amphiboles examined here are representative of the suite at this locality, and their characterization is part of (1) the work of RFM on the minerals from this locality, and (2) the work of FCH on SRO in amphiboles (Hawthorne 1997, Hawthorne et al. 1996a, b, 2000).

\section{EXPERIMENTAL AND RESULTS}

The sample codes and amphibole names used in this work are given in Table 1, sorted in order of decreasing Si content in $a p f u$ (atoms per formula unit).

\section{$X$-ray data collection and structure refinement}

Experimental details are as described by Oberti et al. (1992). Cell dimensions, $R$ indices and other data relevant to crystallographic data collection and structure refinement are given in Table 2. Final atom coordinates and anisotropic-displacement factors are listed in Table 3, selected interatomic distances and angles are given in Table 4, and refined site-scattering values (in

\begin{tabular}{lcl}
\multicolumn{3}{c}{$\begin{array}{c}\text { TABLE 1. SAMPLE NUMBERS AND NAMES OF AMPHIBOLES } \\
\text { FROM THE BEAR LAKE DIGGINGS, ONTARIO }\end{array}$} \\
\hline Sample Number & SEQ & \multicolumn{1}{c}{ Name } \\
\hline BL TREM & 757 & $\begin{array}{l}\text { Fluorotremolite } \\
\text { BL 8 }\end{array}$ \\
BL 10 & 761 & Fluororichterite \\
BL 11 & 721 & Potassian fluoro-magnesiokatophorite \\
\hline
\end{tabular}

TABLE 2. CRYSTAL DATA AND MISCELLANEOUS STRUCTURE-REFINEMENT INFORMATION FOR THE BEAR LAKE AMPHIBOLES

\begin{tabular}{lcccc}
\hline & 757 & 761 & 721 & 762 \\
\hline$a(A)$ & $9.868(3)$ & $9.866(2)$ & $9.888(3)$ & $9.887(3)$ \\
$b$ & $18.033(7)$ & $18.019(4)$ & $18.022(6)$ & $18.023(9)$ \\
$c$ & $5.273(3)$ & $5.274(1)$ & $5.290(2)$ & $5.292(2)$ \\
$\beta\left({ }^{\circ}\right)$ & $104.66(2)$ & $104.58(2)$ & $104.72(3)$ & $104.66(3)$ \\
$V\left(A^{3}\right)$ & 907.7 & 907.4 & 911.7 & 912.2 \\
Space group & $C 2 / m$ & $C 2 / m$ & $C 2 / m$ & $C 2 / m$ \\
$Z$ & 2 & 2 & 2 & 2 \\
No. of $: F \vdots$ & 1375 & 1377 & 1380 & 1384 \\
$\mid F_{i}>50$ & 902 & 1171 & 1086 & 974 \\
$R($ obs) $\%$ & 1.6 & 1.5 & 2.2 & 1.6 \\
\hline
\end{tabular}


epfu: electrons per formula unit) are given in Table 5 . Structure factors may be obtained from The Depository of Unpublished Data, CISTI, National Research Council, Ottawa, Ontario K1A 0S2.

\section{Electron- and ion-microprobe analysis}

Subsequent to the experimental crystallographic work, the crystals used in the collection of the X-ray intensity data were mounted, polished, and characterized by electron- and ion-microprobe analysis following the procedures described by Oberti et al. (1992) and Ottolini et al. (1993). The $\mathrm{Fe}^{3+}$ and $\mathrm{Fe}^{2+}$ contents of the unit formulae were calculated from the structural results and were subsequently put back into the formulanormalization process. The structural results indicate no significant dehydroxylation, and unit formulae were normalized on the basis of $24(\mathrm{O}, \mathrm{OH}, \mathrm{F})$ with $\mathrm{OH}+\mathrm{F}=$ $2.0 \mathrm{apfu}$. The chemical compositions and unit formulae are given in Table 6 .

\section{DISCUSSION}

The site populations were assigned on the basis of the refined site-scattering values (Table 5), the unit formulae calculated from the results of microprobe analysis (Table 6), mean bond-length arguments and the electroneutrality requirement. There is very close agreement between the site scattering at the $C$-, $B$ - and $A$-group sites and the equivalent scattering calculated from the unit formula (Table 5), the mean deviations being $0.4,0.0,0.0$ and 1.4 epfu, respectively.

\section{The $T(1)$ and $T(2)$ sites}

Long-range order of $\mathrm{Si}$ and $\mathrm{Al}$ over the $T(1)$ and $T(2)$ sites in amphibole has been considered by Oberti et al. (1995a), who proposed equations relating mean bondlength to $\mathrm{Al}$ content at these sites. Application of these equations to the $\langle T-\mathrm{O}\rangle$ bond-lengths of Table 4 indicate that ${ }^{[4]} \mathrm{Al}$ is completely ordered at the $T(1)$ site in all

TABLE 3. ATOM COORDINATES AND DISPLACEMENT PARAMETERS $\left(\AA^{2}\right)$ FOR THE BEAR LAKE AMPHIBOLES

\begin{tabular}{|c|c|c|c|c|c|c|c|c|c|}
\hline & $x$ & $y$ & $z$ & $\beta_{11}$ & $\beta_{22}$ & $\beta_{33}$ & $\beta_{12}$ & $\beta_{13}$ & $\beta_{23}$ \\
\hline \multicolumn{10}{|c|}{ Crystal 757} \\
\hline$O(1)$ & 0.11174 & 0.08580 & 0.21765 & 0.0012 & 0.0004 & 0.0044 & 0 & 0.0005 & -0.0001 \\
\hline$O(2)$ & 0.11886 & 0.17044 & 0.72518 & 0.0016 & 0.0005 & 0.0043 & -0.0001 & 0.0010 & -0.0001 \\
\hline$O(3)$ & 0.10801 & 0 & 0.71486 & 0.0023 & 0.0005 & 0.0066 & 0 & 0.0007 & 0 \\
\hline$O(4)$ & 0.36382 & 0.24797 & 0.79421 & 0.0026 & 0.0004 & 0.0054 & -0.0004 & 0.0013 & -0.0002 \\
\hline$O(4)$ & 0.34598 & 0.13269 & 0.09692 & 0.0016 & 0.0006 & 0.0048 & -0.0001 & 0.0006 & 0.0006 \\
\hline$O(6)$ & 0.34304 & 0.11829 & 0.58939 & 0.0018 & 0.0005 & 0.0051 & 0.0001 & 0.0006 & -0.0006 \\
\hline$O(7)$ & 0.33680 & 0 & 0.29379 & 0.0023 & 0.0003 & 0.0099 & 0 & 0.0011 & 0 \\
\hline$\pi(1)$ & 0.27939 & 0.08429 & 0.29682 & 0.0012 & 0.0003 & 0.0030 & 0 & 0.0004 & -0.0001 \\
\hline$T(2)$ & 0.28757 & 0.17119 & 0.80386 & 0.0013 & 0.0003 & 0.0030 & -0.0001 & 0.0006 & 0.0000 \\
\hline$M(1)$ & 0 & 0.08819 & $1 / 2$ & 0.0016 & 0.0003 & 0.0034 & 0 & 0.0009 & 0 \\
\hline$M(2)$ & 0 & 0.17786 & 0 & 0.0013 & 0.0003 & 0.0037 & 0 & 0.0006 & 0 \\
\hline$M(3)$ & 0 & 0 & 0 & 0.0017 & 0.0004 & 0.0035 & 0 & 0.0004 & 0 \\
\hline$M(4)$ & 0 & 0.27767 & $1 / 2$ & 0.0025 & 0.0004 & 0.0078 & 0 & 0.0029 & 0 \\
\hline A & 0 & $1 / 2$ & 0 & 0.0009 & 0.0006 & 0.0075 & 0 & 0.0026 & 0 \\
\hline$A(m)$ & 0.0361 & $1 / 2$ & 0.0828 & 0.0087 & 0.0020 & 0.0236 & 0 & 0.0081 & 0 \\
\hline$A(2)$ & 0 & 0.4594 & 0 & 2.9 & & & & & \\
\hline $\mathrm{H}$ & 0.195 & 0 & 0.775 & 0.4 & & & & & \\
\hline \multicolumn{10}{|c|}{ Crystal 761} \\
\hline$O(1)$ & 0.11141 & 0.08574 & 0.21758 & 0.0013 & 0.0004 & 0.0041 & -0.0001 & 0.0008 & -0.0001 \\
\hline$O(2)$ & 0.11874 & 0.17024 & 0.72576 & 0.0012 & 0.0006 & 0.0046 & -0.0001 & 0.0009 & -0.0002 \\
\hline$O(3)$ & 0.10729 & 0 & 0.71471 & 0.0021 & 0.0006 & 0.0063 & 0 & 0.0011 & 0 \\
\hline$O(4)$ & 0.36368 & 0.24830 & 0.79410 & 0.0024 & 0.0005 & 0.0063 & -0.0004 & 0.0015 & -0.0002 \\
\hline$O(4)$ & 0.34668 & 0.13244 & 0.09605 & 0.0022 & 0.0009 & 0.0065 & -0.0001 & 0.0011 & 0.0008 \\
\hline$O(6)$ & 0.34321 & 0.11793 & 0.58993 & 0.0018 & 0.0007 & 0.0050 & 0 & 0.0008 & -0.0007 \\
\hline$O(7)$ & 0.33787 & 0 & 0.29323 & 0.0019 & 0.0004 & 0.0104 & 0 & 0.0009 & 0 \\
\hline$T(1)$ & 0.27948 & 0.08442 & 0.29672 & 0.0012 & 0.0003 & 0.0032 & 0 & 0.0005 & 0 \\
\hline$T(2)$ & 0.28752 & 0.17133 & 0.80369 & 0.0011 & 0.0004 & 0.0031 & -0.0001 & 0.0007 & -0.0001 \\
\hline$M(1)$ & 0 & 0.08845 & $1 / 2$ & 0.0016 & 0.0004 & 0.0037 & 0 & 0.0010 & 0 \\
\hline$M(2)$ & 0 & 0.17821 & 0 & 0.0015 & 0.0005 & 0.0051 & 0 & 0.0010 & 0 \\
\hline$M(3)$ & 0 & 0 & 0 & 0.0016 & 0.0003 & 0.0034 & 0 & 0.0007 & 0 \\
\hline$M(4)$ & 0 & 0.27741 & $1 / 2$ & 0.0029 & 0.0006 & 0.0096 & 0 & 0.0034 & 0 \\
\hline$A$ & 0 & $1 / 2$ & 0 & 0.0039 & 0.0006 & 0.0258 & 0 & 0.0092 & 0 \\
\hline$A(m)$ & 0.0415 & $1 / 2$ & 0.0909 & 0.0035 & 0.0022 & 0.0205 & 0 & 0.0061 & 0 \\
\hline$A(2)$ & 0 & 0.4712 & 0 & 0.0075 & 0.0001 & 0.0431 & 0 & 0.0037 & 0 \\
\hline $\mathrm{H}$ & 0.190 & 0 & 0.794 & 1.8 & & & & & \\
\hline
\end{tabular}


TABLE 3 (continued). ATOM COORDINATES AND DISPLACEMENT PARAMETERS $\left(\AA^{2}\right)$ FOR THE BEAR LAKE AMPHIBOLES

\begin{tabular}{|c|c|c|c|c|c|c|c|c|c|}
\hline & $x$ & $y$ & $z$ & $\beta_{11}$ & $\beta_{22}$ & $\beta_{33}$ & $\beta_{12}$ & $\beta_{13}$ & $\beta_{23}$ \\
\hline \multicolumn{10}{|c|}{ Crystal 721} \\
\hline$O(1)$ & 0.11024 & 0.08651 & 0.21762 & 0.0021 & 0.0006 & 0.0066 & -0.0002 & 0.0011 & -0.0001 \\
\hline$O(2)$ & 0.11935 & 0.17063 & 0.72816 & 0.0018 & 0.0007 & 0.0074 & 0 & 0.0010 & -0.0001 \\
\hline$O(3)$ & 0.10643 & 0 & 0.71326 & 0.0029 & 0.0006 & 0.0102 & 0 & 0.0015 & 0 \\
\hline$O(4)$ & 0.36385 & 0.24892 & 0.79370 & 0.0033 & 0.0006 & 0.0099 & -0.0004 & 0.0021 & -0.0002 \\
\hline$O(4)$ & 0.34756 & 0.13323 & 0.09709 & 0.0024 & 0.0011 & 0.0088 & 0.0001 & 0.0011 & 0.0012 \\
\hline$O(6)$ & 0.34333 & 0.11807 & 0.59368 & 0.0024 & 0.0008 & 0.0103 & 0.0001 & 0.0010 & -0.0008 \\
\hline$O(7)$ & 0.33854 & 0 & 0.29273 & 0.0029 & 0.0006 & 0.0159 & 0 & 0.0011 & 0.0000 \\
\hline$T(1)$ & 0.27994 & 0.08484 & 0.29855 & 0.0017 & 0.0004 & 0.0054 & 0 & 0.0007 & 0.0000 \\
\hline$T(2)$ & 0.28855 & 0.17151 & 0.80566 & 0.0017 & 0.0004 & 0.0055 & -0.0001 & 0.0009 & 0.0000 \\
\hline$M(1)$ & 0 & 0.08908 & $1 / 2$ & 0.0021 & 0.0005 & 0.0060 & 0 & 0.0012 & 0 \\
\hline$M(2)$ & 0 & 0.17910 & 0 & 0.0019 & 0.0005 & 0.0072 & 0 & 0.0012 & 0 \\
\hline$M(3)$ & 0 & 0 & 0 & 0.0021 & 0.0004 & 0.0057 & 0 & 0.0007 & 0 \\
\hline$M(4)$ & 0 & 0.27800 & $1 / 2$ & 0.0034 & 0.0006 & 0.0120 & 0 & 0.0037 & 0 \\
\hline A & 0 & $1 / 2$ & 0 & 0.0045 & 0.0019 & 0.0184 & 0 & 0.0078 & 0 \\
\hline$A(m)$ & 0.0429 & $1 / 2$ & 0.0948 & 0.0053 & 0.0021 & 0.0208 & 0 & 0.0051 & 0 \\
\hline$A(2)$ & 0 & 0.4721 & 0 & 3.2 & & & & & \\
\hline \multicolumn{10}{|c|}{ Cystal 762} \\
\hline$O(1)$ & 0.11006 & 0.08655 & 0.21687 & 0.0017 & 0.0006 & 0.0050 & -0.0002 & 0.0009 & -0.0001 \\
\hline$O(2)$ & 0.11943 & 0.17052 & 0.72834 & 0.0015 & 0.0007 & 0.0060 & -0.0001 & 0.0006 & -0.0002 \\
\hline $\mathrm{O}(3)$ & 0.10592 & 0 & 0.71251 & 0.0027 & 0.0007 & 0.0079 & 0 & 0.0012 & 0 \\
\hline$O(4)$ & 0.36348 & 0.24902 & 0.79434 & 0.0029 & 0.0006 & 0.0088 & -0.0004 & 0.0020 & -0.0003 \\
\hline$O(4)$ & 0.34769 & 0.13328 & 0.09714 & 0.0018 & 0.0011 & 0.0077 & 0.0002 & 0.0010 & 0.0013 \\
\hline$O(6)$ & 0.34359 & 0.11807 & 0.59439 & 0.0019 & 0.0008 & 0.0080 & 0 & 0.0012 & -0.0008 \\
\hline$O(7)$ & 0.33846 & 0 & 0.29238 & 0.0024 & 0.0005 & 0.0139 & 0 & 0.0008 & 0 \\
\hline$T(1)$ & 0.27989 & 0.08495 & 0.29842 & 0.0012 & 0.0004 & 0.0042 & -0.0001 & 0.0004 & -0.0001 \\
\hline$T(2)$ & 0.28872 & 0.47153 & 0.80567 & 0.0012 & 0.0004 & 0.0043 & -0.0001 & 0.0007 & 0.0000 \\
\hline$M(1)$ & 0 & 0.08890 & $1 / 2$ & 0.0019 & 0.0005 & 0.0044 & 0 & 0.0010 & 0 \\
\hline$M(2)$ & 0 & 0.17925 & 0 & 0.0014 & 0.0005 & 0.0056 & 0 & 0.0011 & 0 \\
\hline$M(3)$ & 0 & 0 & 0 & 0.0017 & 0.0003 & 0.0043 & 0 & 0.0005 & 0 \\
\hline$M(4)$ & 0 & 0.27789 & $1 / 2$ & 0.0032 & 0.0007 & 0.0113 & 0 & 0.0038 & 0 \\
\hline A & 0 & $1 / 2$ & 0 & 0.0031 & 0.0021 & 0.0144 & 0 & 0.0056 & 0 \\
\hline$A(m)$ & 0.0422 & $1 / 2$ & 0.0936 & 0.0054 & 0.0022 & 0.0203 & 0 & 0.0047 & 0 \\
\hline$A(2)$ & 0 & 0.4719 & 0 & 4.2 & & & & & \\
\hline
\end{tabular}

of the Bear Lake amphiboles. Moreover, the $\langle T(1)-\mathrm{O}>$ values of Table 4 and the ${ }^{[4]} \mathrm{Al}$ contents of Table 6 are in almost exact agreement with the predictive equation of Oberti et al. (1995a), and the site populations (Table 7) were assigned accordingly.

The $M(1), M(2)$ and $M(3)$ sites

The unit formulae derived from renormalization of the microprobe data indicate that there are seven scattering species $\left(\mathrm{Al}, \mathrm{Ti}^{4+}, \mathrm{Fe}, \mathrm{Mn}, \mathrm{Zn}, \mathrm{Li}\right.$ and $\mathrm{Mg}$ ) distributed over these three sites. Where there are more than two scattering species distributed over more than one site, the site-scattering values cannot provide a unique solution for the site populations (Hawthorne 1983b). However, combination of the refined site-scattering values with the results of microprobe analysis and the detailed stereochemical changes that accompany changes in site chemistry can give reliable site-populations (Ungaretti et al. 1983, Hawthorne et al. 1993, 1996a, Oberti et al. 1992, 1993, 1995a, b) in complex natural amphiboles.

Of the seven scattering species noted above, $\mathrm{Fe}$ and Mn can each occur in more than one valence state in amphiboles, further complicating the problem of sitepopulation assignment. We will assume that Fe can occur as both $\mathrm{Fe}^{2+}$ and $\mathrm{Fe}^{3+}$, and that $\mathrm{Mn}$ occurs as $\mathrm{Mn}^{2+}$ (as expected by comparison with amphiboles in other environments). As both $\mathrm{Zn}$ and $\mathrm{Mn}$ are present in very small amounts $(\leq 0.05$ apfu), we incorporate them with $\mathrm{Fe}$ as a scattering species: $\mathrm{Fe}^{*}=\mathrm{Fe}^{2+}+\mathrm{Fe}^{3+}+\mathrm{Mn}+$ $\mathrm{Zn}$, as these all have similar X-ray scattering factors. Similarly, $\mathrm{Mg}$ and $\mathrm{Al}$ can be combined in the same fashion: $\mathrm{Mg}^{*}=\mathrm{Mg}+\mathrm{Al}$. This reduces the number of effective scattering species to four: $\mathrm{Mg}^{*}, \mathrm{Fe}^{*}, \mathrm{Ti}$ and Li. Combination of the refined scattering values with stereochemical arguments and the microprobe data now allows assignment of site populations.

Characterization of Li-rich sodic amphiboles (Hawthorne et al. 1992, 1993, 1994, 1996b) has shown 
that $\mathrm{Li}$ is completely ordered at the $M(3)$ site. There is no strong evidence for the assignment of $\mathrm{Ti}$ to the individual $M$-sites in these amphiboles. The only direct evidence for the behavior of $\mathrm{Ti}$ in amphiboles is the neutron-scattering results for kaersutite (Kitamura et al. 1975) and the X-ray results of Oberti et al. (1992) on Fe-poor Ti-rich richterite, both of which show ${ }^{[6]} \mathrm{Ti}$ ordered at the $M(1)$ site and associated with dehydroxylation at the locally associated $\mathrm{O}(3)$ sites. However, small amounts of Ti have usually been assigned to the M(2) site (see Hawthorne 1983a), although there is no direct evidence of this type of behavior; here, we follow this model, but recognize that it may not be correct.

The site populations for $M(1)$ and $M(3)$ can be calculated directly as $\mathrm{Mg}^{*}$ and $\mathrm{Fe}^{*}$ from the refined

\begin{tabular}{|c|c|c|c|c|}
\hline & 757 & 761 & 721 & 762 \\
\hline$T(1)-O(1)$ & 1.601 & 1.605 & 1.623 & 1.625 \\
\hline$T(1)-O(5)$ & 1.630 & 1.631 & 1.645 & 1.644 \\
\hline$T(1)-0(6)$ & 1.631 & 1.631 & 1.641 & 1.645 \\
\hline$T(1)-O(7)$ & 1.624 & 1.628 & 1.638 & 1.640 \\
\hline$\langle T(1)-O\rangle$ & 1.621 & 1.624 & 1.637 & 1.639 \\
\hline$T(2)-O(2)$ & 1.611 & 1.612 & 1.618 & 1.619 \\
\hline$T(2)-O(4)$ & 1.583 & 1.584 & 1.590 & 1.588 \\
\hline$T(2)-O(5)$ & 1.659 & 1.660 & 1.654 & 1.655 \\
\hline$T(2)-O(6)$ & 1.674 & 1.676 & 1.669 & 1.667 \\
\hline$\langle T(2)-O\rangle$ & 1.631 & 1.633 & 1.633 & 1.632 \\
\hline$T(1)-O(5)-T(2)$ & 136.500 & 136.200 & 136.000 & 136.000 \\
\hline$T(1)-O(6)-T(2)$ & 137.700 & 137.400 & 137.700 & 137.500 \\
\hline$T(1)-O(7)-T(1)$ & 138.800 & 138.200 & 137.900 & 138.000 \\
\hline$M(1)-O(1) \times 2$ & 2.065 & 2.062 & 2.061 & 2.063 \\
\hline$M(1)-O(2) \times 2$ & 2.069 & 2.064 & 2.070 & 2.073 \\
\hline$M(1)-\mathrm{O}(3) \times 2$ & 2.083 & 2.083 & 2.087 & 2.081 \\
\hline$\langle M(1)-O\rangle$ & 2.072 & 2.070 & 2.073 & 2.072 \\
\hline$M(2)-O(1) \times 2$ & 2.156 & 2.160 & 2.159 & 2.159 \\
\hline$M(2)-O(2) \times 2$ & 2.087 & 2.083 & 2.085 & 2.085 \\
\hline$M(2)-O(4) \times 2$ & 2.008 & 2.002 & 1.985 & 1.983 \\
\hline$\langle M(2)-O\rangle$ & 2.084 & 2.082 & 2.076 & 2.076 \\
\hline$M(3)-O(1) \times 4$ & 2.070 & 2.058 & 2.075 & 2.074 \\
\hline$M(3)-O(3) \times 2$ & 2.051 & 2.046 & 2.054 & 2.054 \\
\hline$\langle M(3)-O\rangle$ & 2.064 & 2.061 & 2068 & 2067 \\
\hline$M(4)-O(2) \times 2$ & 2.412 & 2.412 & 2.423 & 2.424 \\
\hline$M(4)-O(4) \times 2$ & 2.341 & 2.341 & 2.350 & 2.355 \\
\hline$M(4)-O(5) \times 2$ & 2.794 & 2.801 & 2.782 & 2.784 \\
\hline$M(4)-O(6) \times 2$ & 2.552 & 2.558 & 2.558 & 2.559 \\
\hline$\langle M(4)-O\rangle$ & 2.525 & 2.528 & 2.528 & 2.531 \\
\hline$A O(5) \times 4$ & 2.948 & 2.937 & 2.949 & 2.948 \\
\hline$A-O(6) \times 4$ & 3.153 & 3.147 & 3.139 & 3.138 \\
\hline$A-O(7) \times 2$ & 2.501 & 2.489 & 2.490 & 2.489 \\
\hline$\langle A-O\rangle$ & 2.940 & 2.931 & 2.933 & 2.932 \\
\hline$A(m)-O(5) \times 2$ & 3.053 & 3.069 & 3.083 & 3.080 \\
\hline$A(m)-O(5) \times 2$ & 2.922 & 2.904 & 2.920 & 2.921 \\
\hline$A(m)-O(6) \times 2$ & 2.814 & 2.771 & 2.751 & 2.754 \\
\hline$A(m)-O(7)$ & 2.493 & 2.501 & 2.500 & 2.497 \\
\hline$A(m)-O(7)$ & 3.208 & 3.166 & 3.153 & 3.164 \\
\hline$A(m)-O(7)$ & 2.603 & 2.595 & 2.607 & 2.605 \\
\hline$\langle A(m)-O\rangle$ & 2.876 & 2.861 & 2.863 & 2.864 \\
\hline$A(2)-O(5) \times 2$ & 2.392 & 2.534 & 2.555 & 2.553 \\
\hline$A(2)-O(6) \times 2$ & 2.712 & 2.823 & 2.822 & 2.819 \\
\hline$A(2)-O(7) \times 2$ & 2.605 & 2.543 & 2.541 & 2.540 \\
\hline$\langle A(2)-O\rangle$ & 2.570 & 2.633 & 2.639 & 2.637 \\
\hline O(3)-H & 0.84 & 0.82 & & \\
\hline
\end{tabular}

Standard deviations are $\leq 1$ in the final digit (except for $A-O$ distances). site-scattering values of Table 5. The $\mathrm{Mg}^{*}$ and $\mathrm{Fe}^{*}$ contents of $M(2)$ can be calculated from the refined site-scattering value for the $M(2)$ site after subtracting the scattering due to the amount of Ti present. The mean bond-lengths at $M(1)$ and $M(3)$ indicate that the $\mathrm{Fe}^{*}$ at these sites is completely in the divalent state. Except for crystal 757, the mean bond-length at $M(2)$ indicates that there must be small $(<0.72 \AA$; radii from Shannon 1976) trivalent cations at $M(2)$, and all ${ }^{[6]} \mathrm{Al}$ and $\mathrm{Fe}^{3+}$ were assigned to this site. The $\mathrm{Fe}^{3+}$ content of $M(2)$ was calculated from the mean bond-length at that site, and the site populations were assigned as $\mathrm{Mg}+\mathrm{Al}+$ $\mathrm{Ti}+\mathrm{xFe}^{2+}+\mathrm{yFe}^{3+}$, with $\mathrm{x}+\mathrm{y}$ constrained by the $\mathrm{Fe}^{*}$ site-population assigned to $M(2)$. For crystal 757, the $<M(3)-\mathrm{O}>$ bond-length is shorter than expected for the assigned site-population expressed as $\mathrm{Mg}+\mathrm{Fe}^{2+}$, and so the small amount of ${ }^{[6]} \mathrm{Al}$ present in this crystal (Table 6) was assigned to $M(3)$ ( $c f$. Oberti et al. 1995b).

The $M(4), A$ and $\mathrm{O}(3)$ site-populations were assigned from the unit formulae of Table 6 , and are almost exactly in agreement with the refined site-scattering values. Final site-populations are given in Table 7.

\section{SRO AND ITS CONSTRAINTS ON CHEMICAL VARIABILITY}

Of particular interest in monoclinic amphiboles is the variation in order of the cations occupying the $A$ cavity. This issue has been addressed by Hawthorne \& Grundy (1972, 1978), Papike et al. (1969), Heritsch (1955), Boschmann et al. (1994), Docka et al. (1980), Prewitt (1963), Gibbs \& Prewitt (1968) and Cameron et al. (1983). The details of the mechanism controlling this ordering were finally identified by Hawthorne et al. (1996a), who showed that the observed electron-density distributions within the $A$ cavity, and their variation as a function of site populations in the amphibole structure, can be interpreted in terms of a series of short-range configurations involving the $M(4), \mathrm{O}(3)$ and $A$ sites. The relative frequency of occurrence of these patterns of SRO (Short-Range Order) was identified, and

TABLE 5. REFINED* SITE-SCATTERING VALUES (epfu) THE UNT FORMULA (DENOTED AS EMP) FOR BEAR LAKE AMPHIBOLES

\begin{tabular}{lrrrr}
\hline & 757 & 761 & 721 & 762 \\
\hline$M(1)$ & 24.8 & 24.9 & 28.7 & 29.1 \\
$M(2)$ & 25.8 & 26.9 & 37.7 & 38.5 \\
$M(3)$ & 12.5 & 12.3 & 14.2 & 14.5 \\
$\sum M(1,2,3)$ & 63.2 & 64.0 & 80.6 & 82.1 \\
$\sum M(1,2,3)^{\text {EMP }}$ & 63.1 & 63.9 & 80.5 & 82.0 \\
$M(4)$ & 36.2 & 35.6 & 33.1 & 33.2 \\
$M(4)^{\text {EMP }}$ & 36.5 & 35.5 & 33.1 & 32.6 \\
$A^{\text {EMP }}$ & 5.5 & 6.7 & 11.1 & 12.3 \\
O\{3) & 5.3 & 7.1 & 11.2 & 11.6 \\
O(3) & 16.8 & 17.9 & 17.5 & 17.5 \\
\hline
\end{tabular}

* standard deviations are $\leq 2$ in the final digit. 


\begin{tabular}{|c|c|c|c|c|}
\hline & 757 & 761 & 721 & 762 \\
\hline $\mathrm{SiO}_{2}$ & 58.34 & 57.27 & 50.71 & 50.46 \\
\hline $\mathrm{Al}_{2} \mathrm{O}_{3}$ & 0.10 & 0.68 & 3.83 & 4.02 \\
\hline $\mathrm{TiO}_{2}$ & 0.02 & 0.04 & 0.58 & 0.74 \\
\hline $\mathrm{Fe}_{2} \mathrm{O}_{3}$ & 0.00 & 0.59 & 4.37 & 4.43 \\
\hline $\mathrm{FeO}$ & 2.16 & 1.86 & 7.47 & 8.25 \\
\hline $\mathrm{MnO}$ & 0.19 & 0.11 & 0.42 & 0.40 \\
\hline $\mathrm{ZnO}$ & 0.04 & 0.06 & 0.06 & 0.03 \\
\hline $\mathrm{MgO}$ & 22.62 & 22.83 & 15.81 & 15.06 \\
\hline $\mathrm{CaO}$ & 10.91 & 9.91 & 7.91 & 7.53 \\
\hline $\mathrm{Na}_{2} \mathrm{O}$ & 2.12 & 3.20 & 4.52 & 4.70 \\
\hline $\mathrm{K}_{2} \mathrm{O}$ & 1.01 & 0.99 & 1.60 & 1.69 \\
\hline $\mathrm{Li}_{2} \mathrm{O}$ & 0.00 & 0.00 & 0.04 & 0.04 \\
\hline$F^{2}$ & 1.34 & 1.65 & 2.63 & 2.66 \\
\hline$\left(\mathrm{H}_{2} \mathrm{O}\right)$ & 1.54 & 1.39 & 0.81 & 0.79 \\
\hline $\mathrm{O}=\mathrm{F}$ & -0.56 & -0.69 & -1.11 & -1.12 \\
\hline Total & 99.83 & 99.89 & 99.65 & 99.68 \\
\hline $\mathrm{Si}$ & 8.035 & 7.909 & 7.374 & 7.362 \\
\hline Al & 0.000 & 0.091 & 0.626 & 0.638 \\
\hline$\Sigma T$ & 8.035 & 8.000 & 8.000 & 8.000 \\
\hline $\mathrm{Al}$ & 0.016 & 0.020 & 0.030 & 0.053 \\
\hline $\mathrm{Tt}$ & 0.002 & 0.004 & 0.063 & 0.081 \\
\hline $\mathrm{Fe}^{3+}$ & 0.000 & 0.061 & 0.478 & 0.486 \\
\hline $\mathrm{Fe}^{2+}$ & 0.249 & 0.215 & 0.908 & 1.007 \\
\hline $\mathrm{Mn}$ & 0.022 & 0.013 & 0.052 & 0.049 \\
\hline $\mathrm{Mg}$ & 4.644 & 4.700 & 3.427 & 3.276 \\
\hline $\mathrm{Zn}$ & 0.004 & 0.006 & 0.006 & 0.003 \\
\hline $\mathrm{Li}$ & 0.000 & 0.000 & 0.023 & 0.023 \\
\hline$\Sigma C$ & 4.937 & 5.019 & 4.987 & 4.978 \\
\hline$\square$ & 0.000 & 0.019 & 0.000 & 0.000 \\
\hline $\mathrm{Ca}$ & 1.610 & 1.466 & 1.232 & 1.177 \\
\hline $\mathrm{Na}$ & 0.390 & 0.515 & 0.768 & 0.823 \\
\hline$\Sigma B$ & 2.000 & 2.000 & 2.000 & 2.000 \\
\hline $\mathrm{Na}$ & 0.176 & 0.342 & 0.506 & 0.507 \\
\hline K & 0.177 & 0.174 & 0.297 & 0.315 \\
\hline$\Sigma A$ & 0.353 & 0.516 & 0.803 & 0.822 \\
\hline$F$ & 0.584 & 0.721 & 9.210 & 1.277 \\
\hline $\mathrm{OH}^{*}$ & 1.416 & 1.279 & 0.790 & 0.723 \\
\hline
\end{tabular}

${ }^{*} \mathrm{OH}$ calculated as $(2-\mathrm{F})$ apfu.

explained on the basis of local bond-valence requirements (Hawthorne 1997).

Let us examine the detailed variation in chemical composition of these amphiboles in terms of SRO. Figure 1 shows the distribution of electron density within the $A$ cavity for the four Bear Lake amphiboles. The first significant observation is that only the $A(m)$ site is occupied in each of these amphiboles; the $A(2)$ site is vacant. Inspection of Table 6 shows that all Bear Lake amphiboles have significant $\mathrm{K}$ and $\mathrm{Na}$ at the $A$ site. Hawthorne (1983a) reviewed previous work and concluded that $\mathrm{K}$ always occupies the $A(m)$ site. Hawthorne et al. (1996a) identified the patterns of SRO shown in Table 8, listed in terms of their relative stabilities or frequencies. The $A(2)$ site is not occupied in any of the Bear Lake amphiboles (Fig. 1), and hence local arrangements (2) and (5) (Table 8) do not occur in these amphiboles. Thus for patterns of SRO involving ${ }^{A(m)} \mathrm{Na}$, arrangement (1) will be preferred, with arrangements (3) and (4) occurring only if there are residual chemical components after assignment to arrangement (1).

\begin{tabular}{|c|c|c|c|c|c|}
\hline & & 757 & 761 & 721 & 762 \\
\hline$T(1)$ & $\begin{array}{l}\mathrm{Si} \\
\mathrm{Al}\end{array}$ & $\begin{array}{l}4.00 \\
-\end{array}$ & $\begin{array}{l}3.90 \\
0.10\end{array}$ & $\begin{array}{l}3.38 \\
0.62\end{array}$ & $\begin{array}{l}3.37 \\
0.63\end{array}$ \\
\hline$T(2)$ & $\mathrm{Si}$ & 4.00 & 4.00 & 4.00 & 4.00 \\
\hline$M(1)$ & $\begin{array}{l}\mathrm{Mg} \\
\mathrm{Fe}^{2+}\end{array}$ & $\begin{array}{l}1.93 \\
0.07\end{array}$ & $\begin{array}{l}1.94 \\
0.06\end{array}$ & $\begin{array}{l}1.67 \\
0.33\end{array}$ & $\begin{array}{l}1.62 \\
0.38\end{array}$ \\
\hline$M(2)$ & $\begin{array}{l}\mathrm{Al} \\
\mathrm{Ti}^{4+} \\
\mathrm{Fe}^{3+} \\
\mathrm{Fe}^{2+} \\
\mathrm{Mn}^{2+} \\
\mathrm{Mg}\end{array}$ & $\begin{array}{l}- \\
- \\
- \\
0.15 \\
0.02 \\
1.83\end{array}$ & $\begin{array}{l}0.01 \\
- \\
0.12 \\
0.06 \\
0.01 \\
1.80\end{array}$ & $\begin{array}{l}0.04 \\
0.06 \\
0.44 \\
0.46 \\
0.05 \\
0.95\end{array}$ & $\begin{array}{l}0.07 \\
0.08 \\
0.42 \\
0.51 \\
0.05 \\
0.87\end{array}$ \\
\hline$M(3)$ & $\begin{array}{l}\mathrm{Mg}^{2+} \\
\mathrm{Fe}^{2+} \\
\mathrm{Al} \\
\mathrm{Li}\end{array}$ & $\begin{array}{l}0.94 \\
0.03 \\
0.03 \\
-\end{array}$ & $\begin{array}{l}0.97 \\
0.03 \\
- \\
-\end{array}$ & $\begin{array}{l}0.81 \\
0.17 \\
- \\
0.02\end{array}$ & $\begin{array}{l}0.79 \\
0.19 \\
- \\
0.02\end{array}$ \\
\hline$M(4)$ & $\begin{array}{l}\mathrm{Ca} \\
\mathrm{Na}\end{array}$ & $\begin{array}{l}1.61 \\
0.39\end{array}$ & $\begin{array}{l}1.46 \\
0.54\end{array}$ & $\begin{array}{l}1.23 \\
0.77\end{array}$ & $\begin{array}{l}1.18 \\
0.82\end{array}$ \\
\hline A & $\begin{array}{l}\mathrm{Na} \\
\mathrm{K}\end{array}$ & $\begin{array}{l}0.81 \\
-\end{array}$ & $\begin{array}{l}0.32 \\
0.18\end{array}$ & $\begin{array}{l}0.51 \\
0.30\end{array}$ & $\begin{array}{l}0.51 \\
0.32\end{array}$ \\
\hline$O(3)$ & $\begin{array}{l}\mathrm{F} \\
\mathrm{OH}\end{array}$ & $\begin{array}{l}0.58 \\
1.42\end{array}$ & $\begin{array}{l}0.71 \\
1.29\end{array}$ & $\begin{array}{l}1.21 \\
0.79\end{array}$ & $\begin{array}{l}1.36 \\
0.64\end{array}$ \\
\hline \multicolumn{6}{|c|}{$\begin{array}{l}\text { TABLE 8. PATTERINS OF SRO INVOLVING CATION SITES ADJACENT } \\
\text { TO THE A CAVITY, IN ORDER OF PREFERENCE* }\end{array}$} \\
\hline $\begin{array}{l}(1) \\
(2) \\
(3)\end{array}$ & $\begin{array}{l}\left.{ }^{* / 4} / 4\right) \\
{ }^{(4 / 4)} \mathrm{Na}- \\
\mathrm{Ma}-\end{array}$ & 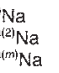 & (4) & $\begin{array}{l}M+4 \mathrm{Ca}-\mathrm{a} \\
{ }^{M / 4} \mathrm{Ca}-\mathrm{O}\end{array}$ & \\
\hline
\end{tabular}

Arrangements (1) and (3) involve $(\mathrm{Na}+\mathrm{K})$ at the $A(m)$ site and $\mathrm{Na}$ at the $M(4)$ site, and hence require that the amounts of these components be equal in these amphiboles; inspection of Figure 2 shows that this is the case. Inspection of Table 8 shows that arrangement (1) involves $\mathrm{F}$ at $\mathrm{O}(3)$, whereas arrangement (3) involves $(\mathrm{OH})$ at $\mathrm{O}(3)$. The variation of $\mathrm{F}$ as a function of ${ }^{A}(\mathrm{Na}$ $+\mathrm{K}$ ) is shown in Figure 3. There is a well-developed linear variation. However, if all SRO involved arrangement (1), the slope of the line in Figure 3 would be 2 (broken line in Fig. 3). This is not the case; the slope is less than 2 and hence some ${ }^{A}(\mathrm{Na}+\mathrm{K})$ and ${ }^{M(4)} \mathrm{Na}$ must also be locally involved with ${ }^{\mathrm{O}(3)} \mathrm{OH}$, i.e., arrangement (3).

As these arrangements involve all $(\mathrm{Na}+\mathrm{K})$ at the $A(m)$ site and $\mathrm{Na}$ at the $M(4)$ site, the remaining arrangement(s) must involve ${ }^{M(4)} \mathrm{Ca}-{ }^{\mathrm{O}(3)}(\mathrm{OH}, \mathrm{F})-{ }^{A} \square$. Hawthorne (1997) examined the issue of SRO in amphiboles from a bond-valence perspective and emphasized the importance of defining a FBB (fundamental building block) for patterns of SRO. This FBB involves all symmetrically distinct sites in the structure, and thus the arrangements ${ }^{M(4)} \mathrm{Na}-{ }^{\mathrm{O}(3)}(\mathrm{F}, \mathrm{OH})-{ }^{A}(\mathrm{Na}+\mathrm{K})$ and ${ }^{M(4)} \mathrm{Ca}-$ 


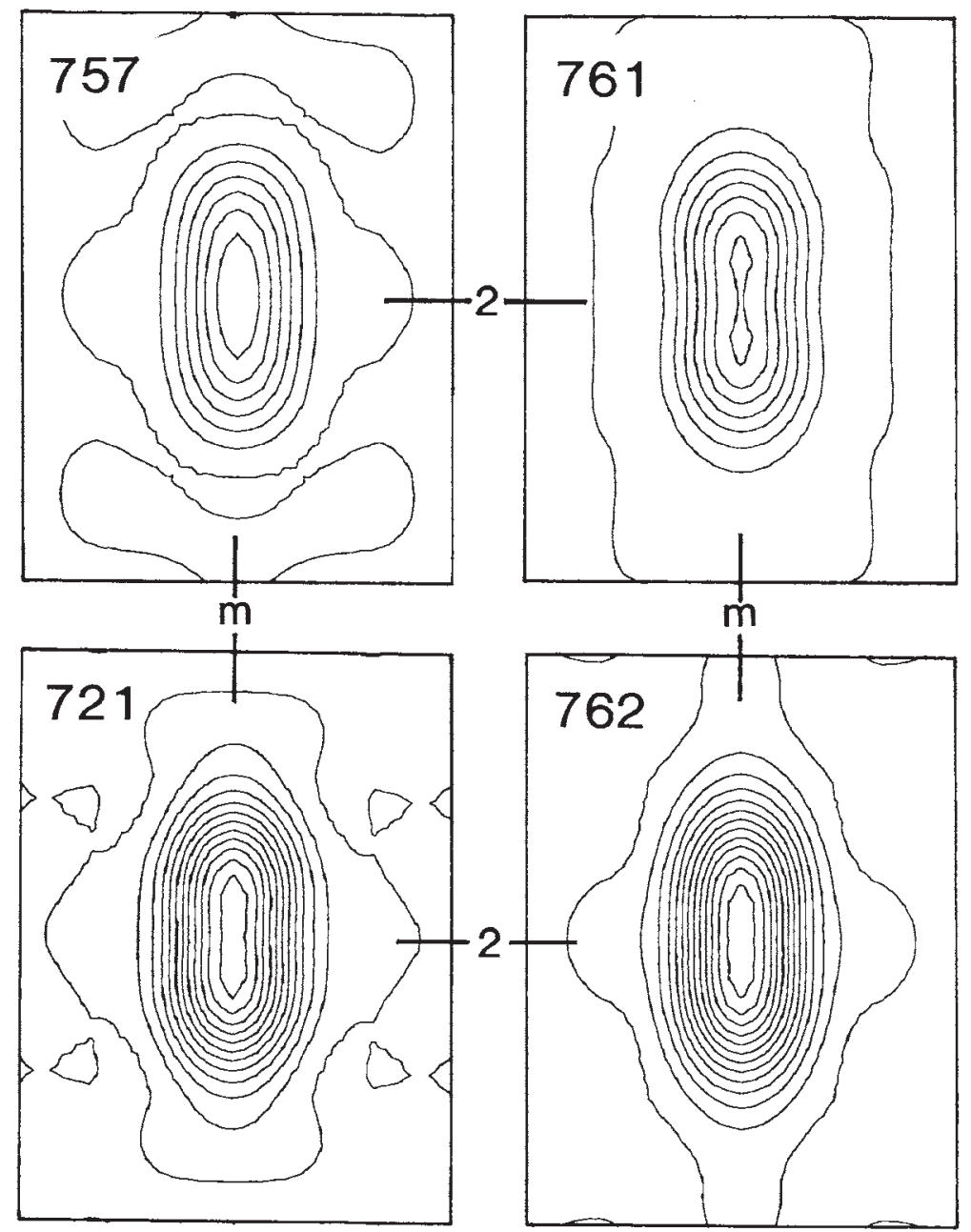

FIG. 1. Difference-Fourier maps through the $A(2 / m)$ site, parallel to $(\overline{2} 01)$ for the amphiboles of this work; the width of each map is $2.8 \AA$, all maps were calculated with the $Y$ axis horizontal (and the mirror plane vertical), with a contour interval of $1 e / \AA^{3}$, and with the $A$ cations removed from the structural model.

${ }^{\mathrm{O}(3)}(\mathrm{OH}, \mathrm{F})-{ }^{A} \square$ dictate the composition of the rest of the crystal. The arrangements ${ }^{M(4)} \mathrm{Na}-\mathrm{O}(3)(\mathrm{F}, \mathrm{OH})-{ }^{A}(\mathrm{Na}+$ $\mathrm{K})$ can involve SRO patterns resembling richterite and katophorite, and the arrangement ${ }^{M(4)} \mathrm{Ca}-{ }^{\mathrm{O}(3)}(\mathrm{OH}, \mathrm{F})-{ }^{A} \square$ can involve SRO patterns resembling tremolite, hornblende and tschermakite. We can identify which patterns are present from the other components in the crystal. Crystal 757 consists of $0.37{ }^{M(4)} \mathrm{Na}-{ }^{\mathrm{O}(3)}(\mathrm{F}, \mathrm{OH})-{ }^{A}(\mathrm{Na}$ $+\mathrm{K})$ and $0.63{ }^{M(4)} \mathrm{Ca}-{ }^{\mathrm{O}(3)}(\mathrm{OH}, \mathrm{F})-{ }^{A} \square$. There is no ${ }^{T} \mathrm{Al}$ in this crystal, and hence the local arrangements must be of the tremolite type and the richterite type (i.e., arrangements not involving $\left.{ }^{T} \mathrm{Al}\right)$. The other ${ }^{M(4)} \mathrm{Na}-$ $\mathrm{O}(3)(\mathrm{F}, \mathrm{OH})-{ }^{A}(\mathrm{Na}+\mathrm{K})$ arrangement thus involves ${ }^{M} \mathrm{Al}$ and ${ }^{T} \mathrm{Al}$ (i.e., it is the katophorite type). The amounts of these arrangements in each crystal are given in Table 9. Note that without the information as to the ordering of the $A$-site cations, these patterns of SRO could not have been identified, as many other arrangements would have been possible with occupancy of the $A(2)$ site [in addition to the $A(m)$ site].

The occurrence of SRO arrangements in amphiboles suggests that the variation in amphibole compositions in petrological processes is much more affected by crystalchemical constraints than has hitherto been apparent. The striking variability in the SRO arrangements and bulk composition among the three amphibole crystals 


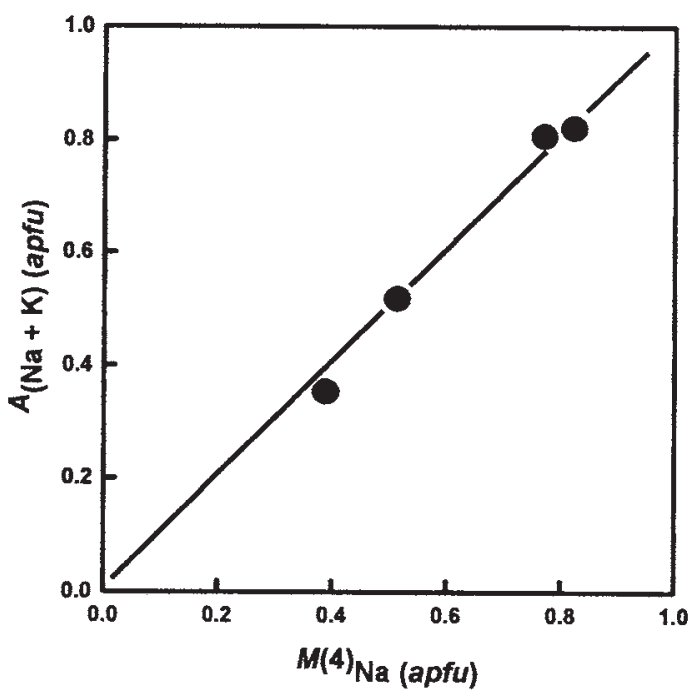

FIG. 2. The variation in ${ }^{A}(\mathrm{Na}+\mathrm{K})$ as a function of ${ }^{M(4)} \mathrm{Na}$ in the Bear Lake amphibole crystals; the line indicates a $1: 1$ relation.

taken from the carbonate dikes (i.e., BL8, BL10 and BL11), each homogeneous and sampled within a few meters of the other, provides important contraints on the origin of these crystals. These ramifications will be explored in a separate article on this poorly documented locality.

\section{ACKNOWLEDGEMENTS}

The authors acknowledge comments by Roberta Flemming, an anonymous reviewer and Associate Editor Dana Griffen. This work was supported by the Natural Sciences and Engineering Research Council of Canada via a Canada Research Chair and Research Tools and Equipment and Major Facilities Access grants to FCH and Discovery Grants to FCH and RFM, and by Canada Foundation for Innovation Grants to FCH. In his student days, Raymond A. McDougall introduced RFM to the fascinating Bear Lake diggings, and supplied the crystals used in this investigation.

\section{REFERENCES}

ANOvitz, L.M. \& EssENE, E.J. (1990): Thermobarometry and pressure-temperature paths in the Grenville Province of Ontario. J. Petrol. 31, 197-241.

Armstrong, H.S. \& GitTins, J. (1968): Geology of Glamorgan and Monmouth townships, Haliburton County. Ontario Geol. Surv., Open-File Rep. $\mathbf{5 0 2 1 .}$

Boschmann, K., Burns, P.C., Hawthorne, F.C., Raudsepp, M. \& TURNOCK, A.C. (1994): A-site disorder in synthetic

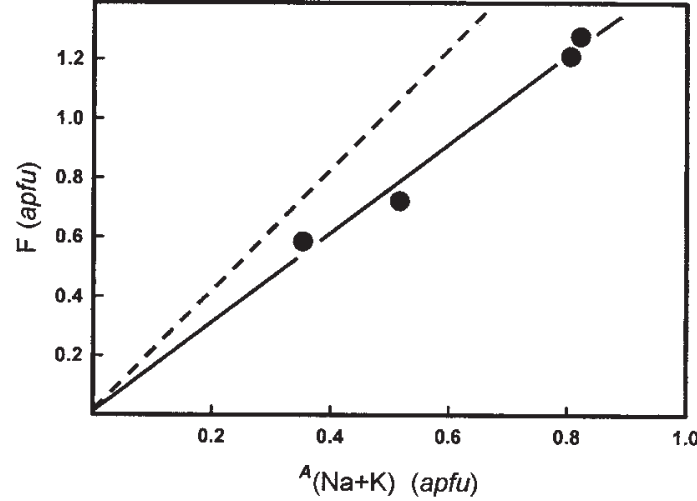

FIG. 3. The variation in $\mathrm{F}$ as a function of ${ }^{A}(\mathrm{Na}+\mathrm{K})$ in the Bear Lake amphibole crystals; the black line is drawn as an aid to the eye, and the broken line indicates a 2:1 relation.

\begin{tabular}{lcccc} 
TABLE 9. PROPORTION OF SRO ARRANGEMENTS & \\
& THE BEAR LAKE AMPHIBOLES & \\
& 757 & 761 & 721 & 762 \\
\hline & 0.37 & 0.43 & 0.16 & 0.18 \\
\hline Richterite & 0.63 & 0.48 & 0.21 & 0.18 \\
Tremolite & 0.00 & 0.09 & 0.63 & 0.64 \\
\hline
\end{tabular}

fluor-edenite, a crystal-structure study. Can. Mineral. 32, 21-30.

BRown, I.D. (1981): The bond-valence method: an empirical approach to chemical structure and bonding. In Structure and Bonding in Crystals II (M. O'Keeffe \& A. Navrotsky, eds.). Academic Press, New York, N.Y. (1-30).

Brown, I.D. (2002): The Chemical Bond in Inorganic Chemistry. The Bond Valence Model. Oxford University Press, Oxford, U.K.

Cameron, M., Sueno, S., Papike, J.J. \& Prewitt, C.T. (1983): High temperature crystal-chemistry of $\mathrm{K}$ and Na fluor-richterites. Am. Mineral. 68, 924-943.

Della Ventura, G., Hawthorne, F.C., Robert, J.-L., DelBove, F., Welch, M.F. \& RaudSEPP, M. (1999): Shortrange order of cations in synthetic amphiboles along the richterite-pargasite join. Eur. J. Mineral. 11, 79-94.

Della Ventura, G., Hawthorne, F.C., Robert, J.-L. \& Iezzi, G. (2003): Synthesis and infrared spectroscopy of amphiboles along the tremolite-pargasite join. Eur. J. Mineral. 15, 341-347.

Della Ventura, G., Robert, J.-L. \& Hawthorne, F.C. (1998): Characterization of OH-F short-range order in potassium-fluor-richterite by infrared spectroscopy in the OH-stretching region. Can. Mineral. 36, 181-185. 
DockA, J.A., Bish, D.L. \& Burnham, C.W. (1980): Positional disorder in clinoamphibole "A" sites. Geol. Soc. Am., Abstr. Programs 12, 44.

EAston, R.M. (2000): Metamorphism of the Canadian Shield, Ontario, Canada. II. Proterozoic metamorphic history. Can. Mineral. 38, 319-344.

Gibbs, G.V. \& PrewitT, C.T. (1968): Amphibole cation site disorder. In Int. Mineral. Assoc., Pap. Proc. Fifth Gen. Meet. (Cambridge, 1966). Mineralogical Society, London, U.K. (abstr.).

HaWTHORNE, F.C. (1983a): The crystal chemistry of the amphiboles. Can. Mineral. 21, 173-480.

HaWTHORNE, F.C. (1983b): Quantitative characterization of site occupancies in minerals. Am. Mineral. 68, 287-306.

HAwTHORNE, F.C. (1997): Short-range order in amphiboles: a bond-valence approach. Can. Mineral. 35, 201-216.

Hawthorne, F.C., Della Ventura, G. \& Robert, J.-L. (1996b): Short-range order of $(\mathrm{Na}, \mathrm{K})$ and $\mathrm{Al}$ in tremolite: an infrared study. Am. Mineral. 81, 782-784.

HAwTHORNE, F.C. \& GRUNDY, H.D. (1972): Positional disorder in the A-site of clino-amphiboles. Nature 235, 72-73.

HawthoRne, F.C. \& GRUNDY, H.D. (1978): The crystal chemistry of the amphiboles. VII. The crystal structure and site-chemistry of potassian-ferri-taramite. Can. Mineral. 16, 53-62.

Hawthorne, F.C., Oberti, R. \& Sardone, N. (1996a): Sodium at the A site in clinoamphiboles: the effects of composition on patterns of order. Can. Mineral. 34, 577-593.

Hawthorne, F.C., Oberti, R., Ungaretti, L. \& Grice, J.D. (1992): Leakeite, $\mathrm{NaNa}_{2}\left(\mathrm{Mg}_{2} \mathrm{Fe}^{3+}{ }_{2} \mathrm{Li}\right) \mathrm{Si}_{8} \mathrm{O}_{22}(\mathrm{OH})_{2}$, a new alkali amphibole from the Kajlidongri manganese mine, Jhabua district, Madhya Pradesh, India. Am. Mineral. 77, 1112-1115.

Hawthorne, F.C., Ungaretti, L., Oberti, R., Bottazzi, P. \& CZAMANSKe, G.K. (1993): Li: an important component in igneous alkali amphiboles. Am. Mineral. 78, 733-745.

Hawthorne, F.C., Ungaretti, L., Oberti, R., Cannillo, E. \& SMELIK, E.A. (1994): The mechanism of ${ }^{[6]} \mathrm{Li}$ incorporation in amphiboles. Am. Mineral. 79, 443-451.

Hawthorne, F.C., Welch, M.D., Della Ventura, G., Liu, ShuangXi, Robert, J.-L. \& Jenkins, D.M. (2000): Shortrange order in synthetic aluminous tremolites: an infrared and triple-quantum MAS NMR study. Am. Mineral. 85, 1716-1724.

HeRitsch, H. (1955): Bemerkungen zur Schriebung der kristallchemischen Formel der Hornblende. Tschermaks Mineral. Petrogr. Mitt. 5, 242-245.

Kitamura, M., Tokonami, M. \& Morimoto, N. (1975): Distribution of titanium atoms in oxy-kaersutite. Contrib. Mineral. Petrol. 51, 167-172.
LENTZ, D.R. (1998): Late-tectonic U-Th-Mo-REE skarn and carbonatitic vein-dyke systems in the southwestern Grenville Province: a pegmatite-related pneumatolytic model linked to marble melting (limestone syntexis). In Mineralized Intrusion-Related Skarn Systems (D.R. Lentz, ed.). Mineral. Assoc. Can., Short Course Ser. 26, 519-657.

Oberti, R., Hawthorne, F.C., Ungaretti, L. \& Cannillo, E. (1995b): ${ }^{6]} \mathrm{Al}$ disorder in amphiboles from mantle peridotites. Can. Mineral. 33, 867-878.

Oberti, R., Hawthorne, F.C., Ungaretti, L. \& Cannillo, E. (1993): The behaviour of $\mathrm{Mn}$ in amphiboles: $\mathrm{Mn}$ in richterite. Eur. J. Mineral. 5, 43-52.

Oberti, R., Ungaretti, L., Cannillo, E. \& Hawthorne, F.C. (1992): The behaviour of Ti in amphiboles. I. Fourand six-coordinate $\mathrm{Ti}$ in richterite. Eur. J. Mineral. 4, 425-439.

Oberti, R., Ungaretti, L., Cannillo, E., Hawthorne, F.C. \& Memmi, I. (1995a): Temperature-dependent Al order-disorder in the tetrahedral double-chain of $C 2 / \mathrm{m}$ amphiboles. Eur. J. Mineral. 7, 1049-1063.

Ottolini, L., Bottazzi, P. \& VAnNuCCI, R. (1993): Quantification of lithium, beryllium and boron in silicates by secondary ion mass spectrometry using conventional energy filtering. Anal. Chem. 65, 1960-1968.

PAPIKe, J.J., Ross, M. \& Clark, J.R. (1969): Crystal-chemical characterization of clinoamphiboles based on five new structure refinements. Mineral. Soc. Am., Spec. Pap. 2, 117-136.

PrewitT, C.T. (1963): Crystal structures of two synthetic amphiboles. Geol. Soc. Am., Spec. Pap. 76, 132-133 (abstr.).

Robert, J.-L., Della Ventura, G., Welch, M.D. \& HaWTHORNE, F.C. (2000): The OH-F substitution in synthetic pargasite at $1.5 \mathrm{kbar}, 850^{\circ} \mathrm{C}$. Am. Mineral. 85, 926-931.

Shannon, R.D. (1976): Revised effective ionic radii and systematic studies of interatomic distances in halides and chalcogenides. Acta Crystallogr. A32, 751-767.

Streepey, M.M., Essene, E.J. \& Van der Pluijm, B.A. (1997): A compilation of thermobarometric data from the Metasedimentary Belt of the Grenville Province, Ontario and New York State. Can. Mineral. 35, 1237-1247.

Ungaretti, L., Lombardo, B., Domeneghetti, C. \& Rossi, G. (1983): Crystal-chemical evolution of amphiboles from eclogitized rocks of the Sesia Lanzo Zone, Italian Western Alps. Bull. Mineral. 106, 645-672.

Received April 4, 2005, revised manuscript accepted April 1, 2006. 
